\title{
Teachers' ICT Adoption in South African Rural Schools: A Study of Technology Readiness and Implications for the South Africa Connect Broadband Policy
}

\section{Samwel Dick Mwapwele}

Postdoctoral Fellow, College of Science, Engineering and Technology (CSET), Science Campus, University of South Africa (UNISA), Florida, Jobannesburg

(iD https://orcid.org/0000-0003-2316-262X

\section{Mario Marais}

Principal Researcher, Council for Scientific and Industrial Research (CSIR), Pretoria

iD https://orcid.org/0000-0003-3302-1230

\section{Sifiso Dlamini}

Researcher, Council for Scientific and Industrial Research (CSIR), Pretoria

(iD https://orcid.org/0000-0002-3756-4980

\section{Judy van Biljon}

SARChI Chair in ICT4D, College of Science, Engineering and Technology (CSET), Science Campus, University of South Africa (UNISA), Florida, Johannesburg

iD https://orcid.org/0000-0002-4646-1641

\begin{abstract}
The South Africa Connect national broadband policy of 2013 aims to ensure that the country achieves universal internet access by 2030, thereby fostering digital skills development. This study investigates one dimension of the South Africa Connect policy objectives, by considering rural teachers' adoption of information and communication technologies (ICTs) for teaching and learning at 24 schools. This research used baseline data from the Information and Communication Technology for Education (ICT4E) project undertaken in rural schools in seven South African provinces. The technology readiness index (TRI) was used as the theoretical lens. We found that the vast majority of the teachers surveyed were optimistic about the use of ICTs for teaching and learning, which suggests teachers' readiness to use ICTs despite the existing financial, technical and digital skills challenges at their schools. We also found that the majority of the schools had policies prohibiting student use of personal digital devices, apart from calculators, on school premises. In our analysis, these policies potentially conflict with the objectives of South Africa Connect. This study contributes to theory and practice by offering empirical evidence of the usefulness of the TRI for presenting teachers' readiness to adopt ICTs in situations of conflicting forces. The study also has the potential to contribute to policy deliberations by highlighting the possible disconnect between the schools' bans on student personal digital devices and the objectives and targets set by the South Africa Connect policy.
\end{abstract}




\section{Keywords}

information and communication technologies (ICTs), schools, rural areas, teachers, adoption, teaching and learning, technology readiness index (TRI), South Africa, national broadband policy, South Africa Connect

\section{Acknowledgements}

This article draws on a conference paper presented at Digital Skills 2019: Digital Innovation and Transformation Conference, 29 August 2019, Boksburg, South Africa. We acknowledge the support for this research from the South African Department of Rural Development and Land Reform (DRDLR) ICT for Education (ICT4E) project. The ICT4E project was funded by the DRDLR and supported by the University of the Free State (UFS) through its training of teachers and National Rural Youth Service Corps (NARYSEC) youth at 24 schools in seven South African provinces. We also acknowledge the support of the ICT4E project research and implementation team at the Meraka Institute of the Council for Scientific and Industrial Research (CSIR). The research upon which this article is based was also supported by the South African Research Chairs Initiative (SARChI) of the Department of Science and Technology and National Research Foundation (Grant No. 98564).

DOI: https://doi.org/10.23962/10539/28658

\section{Recommended citation}

Mwapwele, S. D., Marais, M., Dlamini, S., \& Van Biljon, J. (2019). Teachers'ICT adoption in South African rural schools: A study of technology readiness and implications for the South Africa Connect broadband policy. The African Journal of Information and Communication (AJIC), 24, 1-21. https://doi.org/10.23962/10539/28658

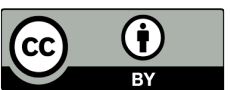

This article is licensed under a Creative Commons Attribution 4.0 International (CC BY 4.0) licence: https://creativecommons.org/licenses/by/4.0

\section{Introduction}

The fourth industrial revolution (4IR) is centred on the application of digital technologies so that distinctions between the physical, digital and biological spaces are reduced. Among the central manifestations of the 4IR are job automation and an always-connected, converged world (Eberhard et al., 2017). For a country to achieve the benefits of the 4IR, emphasis needs to be placed on building citizens' optimism through providing access to, and the skills to operate, digital technologies, i.e., emphasis needs to be placed on building citizens' skills competencies in the use of information and communication technologies (ICTs).

A country's ICT policies guide the adoption and use of technology by explicitly setting out what needs to be done to achieve national goals (Gibson, Broadley, Downie \& Wallet, 2018). Educational technology policy development and implementation 
aim to facilitate the sustainable adoption and application of technology so that it assists the country's education system, through implementation by students, teachers, parents, principals and administrators. ICTs, which include internet, PCs and mobile devices (e.g., mobile phones, tablets and laptops), are used in schools with the expected national goals (outcomes) being improved access to and dissemination of teaching and learning materials (Hennessy, Harrison \& Wamakote, 2010). National goals in education need to align with the United Nations Sustainable Development Goal (SDG) No. 4, which is to ensure that quality education is offered at all educational levels (Department of Basic Education, 2017; Gibson et al., 2018).

In developing countries, ICTs are proposed as tools to assist in reducing the digital divide, especially in education (Rena, 2008) where they can, among other things, provide access to secondary learning materials (Porter et al., 2016) with hard-copy textbooks still being the recommended primary sources (Eberhard et al., 2017). Notwithstanding the concerns raised by Hargittai (2010, p. 93) that researchers should be mindful of the "assumptions about widespread digital skills among [citizens]", African researchers have provided empirical evidence of the efficacy of building digital skills in education and of the spread of digitally enabled education. Kaliisa and Picard (2017), via a systematic review of literature from nine African countries on the use of mobile devices in higher education, find that smartphones are the predominant mobile devices used for learning, followed by tablets.

Rambe and Ng'ambi (2014) have found that students in South Africa can expand their digital skills through the use of Facebook. As a result of the positive empirical evidence witnessed in Ghana, Malawi and South Africa, Porter et al. (2016) conclude by urging relevant authorities in Sub-Saharan Africa to address the challenges faced by youth concerning the use of mobile devices for education. However, there is still very little empirical evidence from Africa on ICT adoption for teaching and learning in schools (Liebenberg, Benade and Ellis (2018) is among the notable exceptions), particularly from the perspective of teachers, and this gap necessitates research of the kind described in this article.

Like other developing countries, South Africa has policies aimed at boosting the adoption and use of ICTs, specifically in education. South Africa Connect, the country's national broadband policy of 2013, mandates the introduction of a broadband connection (with a download speed of at least $100 \mathrm{Mbps}$ ) to every primary school and secondary school as part of an initiative to ensure the countrywide availability of broadband internet access by the year 2030 (DoC, 2013). The policy positions the enhancement of teachers' and principals' internet connectivity as necessary to support access to, and the use of, learning materials that can enhance learning in classrooms and foster the development of students' digital skills. 
Schools in South African rural areas suffer from shortages of teachers and of teaching and learning materials (Waller \& Maxwell,2017). Projects in South Africa, as in other countries around the world, are providing teachers with ICTs in order to assist them with teaching and to increase their ICT knowledge and skills (Botha, Herselman, Rametse \& Maremi, 2017; Frohberg, Göth \& Schwabe, 2009; Roberts \& Vänskä, 2011). One element of focus has been on ensuring that the digital tools diffused in schools are sensitive to the schools' resource challenges and are sustainable. Central to this sustainability dimension are teachers' skills and attitudes with respect to the use of technology.

Many ICT interventions meet with failure when the recipients of the intervention struggle to sustain the tools introduced and used during the project. Among the reasons for such failures, it has been argued, are lack of fit between the ICTs and user need (Alsabawy, Cater-Steel \& Soar, 2011; Avgerou, 2008). To limit the challenges of sustainability of interventions after completion of ICT interventions in school settings, teachers' ICT competencies and attitudes must be assessed, based on the ICTs they have personally adopted and used, prior to the introduction of new ICT tools.

In our study, we collected empirical data from 24 rural schools (primary and secondary) across seven South African provinces in order to seek answers to the following questions:

- what are rural South African teachers' experiences and attitudes in respect of the use of ICTs in support of teaching and learning?

- which technology readiness factors are impacting teachers' ICT adoption in support of teaching and learning?

The overall intention of the research was to interrogate an element of the objectives of the South Africa Connect national broadband policy (rural teacher ICT adoption), and in the process to extend our understanding of the factors that impact teachers' ICT use. The research applied the technology readiness index (TRI) as the theoretical framework to guide the investigation of teachers' ICT readiness and adoption.

\section{Literature review}

\section{ICTs for teaching and learning in African schools}

ICTs have received widespread optimism, adoption, and use in African countries, including use in educational provision (Barakabitze et al., 2019; Kafyulilo, 2014). For teachers, the spread of digital skills offers, among other things, opportunities for formalised recognition of their new competencies-as documented by Botha, Herselman, Rametse and Maremi (2017) in their research into the training of teachers in ICT use in rural schools in South Africa. Botha et al. (2017) looked at a training programme, as part of teacher professional development, whereby teachers received "badges" for skills acquired. Osakwe, Dlodlo and Jere (2017), in their research into 
Namibian secondary school teachers' and learners' perceptions of mobile learning, found that teachers and learners who owned mobile devices were accessing the internet, accessing social media, and searching for information, which shows that they had mastered digital skills and were participating in digitally-enabled informal educational pursuits outside the school setting.

Meanwhile, Yidana and Maazurre (2012) paint a less optimistic picture. They reveal the discomfort faced by Ghanaian teachers in integrating ICTs into their work due to, inter alia, insufficient digital skills caused by lack of integration of ICT adoption into teaching and learning. Omoniyi and Quadri (2013) have found evidence of insufficient ICT competency among a group of surveyed secondary school teachers in Ogun State, Nigeria.

\section{South Africa Connect policy and its application in education}

The South Africa Connect policy, published in 2013 by the Department of Communications (DoC) and currently driven by the newly created (in mid-2019) Department of Communications and Digital Technologies (DCDT), advocates for a digital society characterised by widespread ICT knowledge and use for individuals, communities, organisations, and the society as a whole (DoC, 2013; Hankel et al., 2017). ${ }^{1}$ Digital education modalities, through innovations such as the internet, tablets, digital academic content (embedded in applications) on tablets, and mobile services, are positioned as offering hope to the nation towards attaining improved economic and social development (DoC, 2013) through digital education. Operationalising the policy must include the assessment of both innovations that are currently in use and those that are intended for diffusion and adoption.

South Africa Connect seeks to operationalise elements of South Africa's National Development Plan (NDP) of 2012 (NPC, 2012). The NDP provides a vision for the eradication of poverty in South Africa by the year 2030. Sustainable poverty eradication and education are inseparable (Avgerou, 2008; Fardon \& Furniss, 1994; Ngwenyama, Andoh-Baidoo, Bollou \& Olga, 2006). Education is required to help develop knowledge and skills that assist an individual to either join the job market or create job opportunities for others through innovative discoveries (Rena, 2006). Among other things, the NDP states that "children of today must be guaranteed access to high-quality education and professional training throughout their education and working life" (NPC, 2012, p. 366).

The South Africa Connect policy has, since its adoption in 2013, been augmented by two other policies: the National Integrated ICT Policy White Paper (DTPS, 2016) and the Policy on High Demand Spectrum and Policy Direction on the Licensing of a Wireless Open-Access Network (DTPS, 2019). The Policy on High-Demand

1 The DCDT was formed in June 2019 through the merger of the Department of Communications (DoC) and the Department of Telecommunications and Postal Services (DTPS). 
Spectrum, an extension of the White Paper, has little focus on schools. Meanwhile, the White Paper itself, in naming nine key challenges facing South Africa that ICTs need to assist in addressing, states that one of the challenges is that "[ $t]$ he quality of school education is poor" (DTPS, 2016, p. 8). The White Paper points to evidence in other countries that "connecting a school is often the first step to connecting a community ..." (DTPS, 2016, p. 36). The policy insists on the need, as also stated in South Africa Connect, for schools and clinics to be key points of ICT access.

\section{South African rural schools and demand for technology}

Rural areas are defined as "farms and traditional areas characterized by low population density, low level of economic activity and low level of infrastructure" (Department of Basic Education, 2017, p. 20). Schools in South Africa's rural areas are faced with numerous challenges, including unstable electricity, high dropout rates, poor classroom infrastructure, security problems (Adukaite, Van Zyl, Er \& Cantoni, 2017), and, with particular relevance for this study, shortages of qualified teachers and shortages of teaching and learning materials (Mestry \& Ndhlovu, 2014). The Department of Basic Education (DBE) Rural Education Draft Policy of 2017 states that "it is difficult to recruit, retain and develop qualified teachers in a rural setting due to the distances of schools from towns, poor infrastructure and limited service delivery" (Department of Basic Education, 2017, p. 18). To assist in reducing this and other problems, the policy recommends increased diffusion of ICTs to rural schools.

ICTs are seen as empowering teachers by allowing them to, inter alia, access teaching content on the internet; develop a better understanding of content they are teaching; improve communication with colleagues when seeking support; participate in online training; and become more knowledgeable about ongoing political, social, economic and financial developments in the world (Hennessy et al., 2010; Kopcha, 2012).

\section{Technology readiness index (TRI)}

The technology readiness index (TRI) is a framework, initially developed by Parasuraman, to assess the ability of individuals to adopt and use technology (see Lai, 2008; Parasuraman \& Colby, 2015; Summak, Baglibel \& Samancioglu, 2010). The framework investigates individuals' intentions to adopt and use technology, primarily based on their state of mind rather than their skills (with, however, the recognition that digital skills may influence the state of mind). The TRI uses four concepts to understand an individual's (in this study, the individuals were teachers) state of mind, namely:

- optimism;

- innovativeness;

- discomfort; and

- insecurity (Parasuraman \& Colby, 2015, p. 60). 
In the TRI, optimism is characterised by the presence of a positive mindset, i.e., the belief that one can attain intended goals by using technology (Hennessy et al., 2010; Kopcha, 2012; Summak et al., 2010). For our study, we sought to identify instances where teachers believed that the use of technology could enhance classroom interactions and were thus optimistic that increased levels of learner engagement could be the outcome, together with improved learner results and improved digital skills (Partin \& Lauderdale, 2013).

Innovativeness, in the TRI, refers to actions such as being the first in a cohort to acquire technology, displaying a willingness to use technology, and being a constant information-seeker in respect of new technologies (Falloon, 2013; Ifenthaler \& Schweinbenz, 2013). An innovative individual will, thus, be someone who actively engages with sources of information in order to acquire information on upcoming technologies and the impact they will have on society. Once the technology is widely introduced in a society, the innovator becomes a source of support for colleagues. In the context of our study, we sought evidence of innovativeness in the form of teachers offering technical support to colleagues during the diffusion and adoption of technologies.

Discomfort is conceptualised, in the TRI, as being in evidence when people struggle, for example, to comprehend how technology is used (Frohberg et al., 2009; Ifenthaler \& Schweinbenz, 2013). In our study, we looked for teachers expressing discomfort about potential lack of control regarding the use of technology, and expressing the views that suggested they found technology overwhelming. Further, we looked for teachers showing discomfort through expressing that they had limited knowledge and skills in respect of technology (Yidana \& Maazurre, 2012).

In the TRI, insecurity is seen as resulting from distrust based on, for example, concerns about security and privacy (Ampofo et al., 2014; Summak et al., 2010). Discomfort and insecurity can affect teachers' perceptions of technology and limit the potential value of technology diffusion.

In line with the TRI, teacher optimism and innovativeness were, in our study, positioned as technology enablers, since they would assist teachers in their quest to adopt ICTs. Teacher discomfort and insecurity, meanwhile, were treated, in line with the TRI, as inhibitors of ICT adoption that might not only affect teachers' ICT adoption but might also affect how they viewed ICT use for teaching and learning, and how they viewed other teachers who readily adopt ICTs. 


\section{Research methodology}

The study was conducted under the direction of the Next Generation Enterprises and Institutions cluster at the Council for Scientific and Industrial Research (CSIR). The research was funded by a South African Department of Rural Development and Land Reform (DRDLR) project entitled "Information and Communication Technology for Education" (ICT4E). The 24 rural schools from which we recruited teachers for data collection were primary and secondary schools identified by the DRDLR. The schools were from seven of the nine South African provinces, and 197 teachers served as respondents for data collection.

In South Africa, schools are classified according to the quintile system, starting at quintile 1 for the most disadvantaged schools and ending at quintile 5 for the most affluent schools (Mestry \& Ndhlovu, 2014; Roberts \& Vänskä, 2011). The 24 rural schools from which data was collected were all in either quintiles 1 or 2 . The perprovince breakdown of the 24 schools was as follows:

- Eastern Cape (2 schools);

- Free State (3);

- Gauteng (3);

- KwaZulu-Natal (3);

- Northern Cape (7);

- North West (3); and

- Limpopo (3).

A previous project, called ICT for Rural Education Development (ICT4RED) and conducted in the Eastern Cape Province, developed a curriculum that was used, during the diffusion of tablets in schools, to train teachers on their use. The intention of that project was not only to equip teachers with tablets but also to teach them teaching strategies while using the tablets. The results from the ICT4RED study (see Botha et al., 2017; Herselman \& Botha, 2014; Marais \& Van Biljon, 2017) were used to guide our ICT4E project's approach to understanding ICT adoption by schools. Before commencement of ICT4E, we collected baseline data in order to assess ICTs that teachers had already adopted and were using (1) in their personal lives, and (2) for teaching and learning. The intention of the baseline study was also to identify challenges that teachers faced in using ICTs for teaching and learning so that the ICT4E project could incorporate solutions to the challenges into the curriculum it used. The data on which this article is based, and as reported in the findings section, is a sub-set of the data we collected during that baseline study.

The data collection tool we used was a questionnaire composed of initial demographic questions followed by closed- and open-ended questions. In this article, we focus on the demographic information and the responses from some of the closed-ended questions. The findings from the open-ended questions are discussed in a different publication (see Mwapwele, Marais, Dlamini \& Van Biljon, 2019). 
The questionnaire was self-administered by teachers in the school settings from June to August 2016. Ethical clearance was received from the CSIR Research Ethics Committee (REC) and the principals of the schools where data was collected. The teachers were informed of the objectives of the research, and of ethical guidelines for consent, confidentiality, data collecting and data reporting. Teachers gave consent for data collection before they completed the self-administered questionnaires. We present our findings using a combination of frequency distributions and percentages from the data. In places where teachers did not respond to a particular question, we use "no response" to denote such an instance.

\section{Findings}

\section{Teacher demographics and ICT access and ownership}

Age

Among the 197 teachers surveyed, the youngest was 22 years old, and the oldest was 64. The majority of the teachers were aged between 46 and 50 years old.

\section{Gender}

Among the 197 respondents, there were 129 (65\%) female teachers and 68 (35\%) male teachers.

\section{Teaching experience}

Among the 197 teachers, $128(65 \%)$ had at least 10 years of teaching experience, $43(22 \%)$ had four to nine years of experience, and $25(13 \%)$ had three or fewer years of experience, as represented in Table 1. One teacher did not indicate years of experience.

Table 1: Teachers' teaching experience and positions

\begin{tabular}{|l|c|c|}
\hline \multicolumn{3}{|c|}{ Teaching experience } \\
\hline & Frequency & Percentage \\
\hline 3 years or fewer & 25 & $13 \%$ \\
\hline 4-9 years & 43 & $22 \%$ \\
\hline 10-19 years & 51 & $26 \%$ \\
\hline 20-29 years & 67 & $34 \%$ \\
\hline 30-39 years & 10 & $5 \%$ \\
\hline No response & 1 & $<1 \%$ \\
\hline \multicolumn{3}{|c|}{ Position held at the school } \\
\hline Head of Department & Frequency & Percentage \\
\hline Deputy Principal & 30 & $15 \%$ \\
\hline Principal & 3 & $2 \%$ \\
\hline No additional position & 9 & $5 \%$ \\
\hline No response & 146 & $74 \%$ \\
\hline
\end{tabular}




\section{Administrative positions}

Table 1 also shows the instances where the surveyed teachers held additional positions in their schools, i.e., in addition to their teaching positions. Thirty (15\%) were heads of departments (based on the subjects in which they had specialised), three (2\%) were deputy principals, and nine (5\%) were principals.

\section{Teachers' access to computers (laptop or PC) at school}

It was found that $51(26 \%)$ of the teachers had access to computers for administrative duties at their schools (this included using school secretaries' computers to record academic results and print examinations), $19(10 \%)$ had access to a computer in their school's computer laboratory, and $29(15 \%)$ had access to a computer in their office (where they could use the computer to prepare content for teaching and learning). A total of 97 (49\%) of teachers did not have access to computers at their schools. One teacher did not respond to the question.

\section{Teachers' access to tablets at school}

Figure 1 presents information on teachers' access at tablets at the surveyed schools, with 186 (94\%) of teachers indicating that their school had tablets for both teachers (educators) and learners. Six (3.05\%) of the teachers stated that tablets were available for learners only, four (2\%) of teachers said that tablets were available for teachers only, and one teacher said there were no tablets at the school. The one teacher who stated that there were no tablets at the school was at a school where the rest of the teachers from the same school stated that there were indeed tablets available and that they were used by teachers and learners alike. This indicated a lack of awareness on the part of the teacher in terms of available resources, and possibly some indifference towards the use of ICTs.

\section{Figure 1: Teachers' access to tablets at their schools}

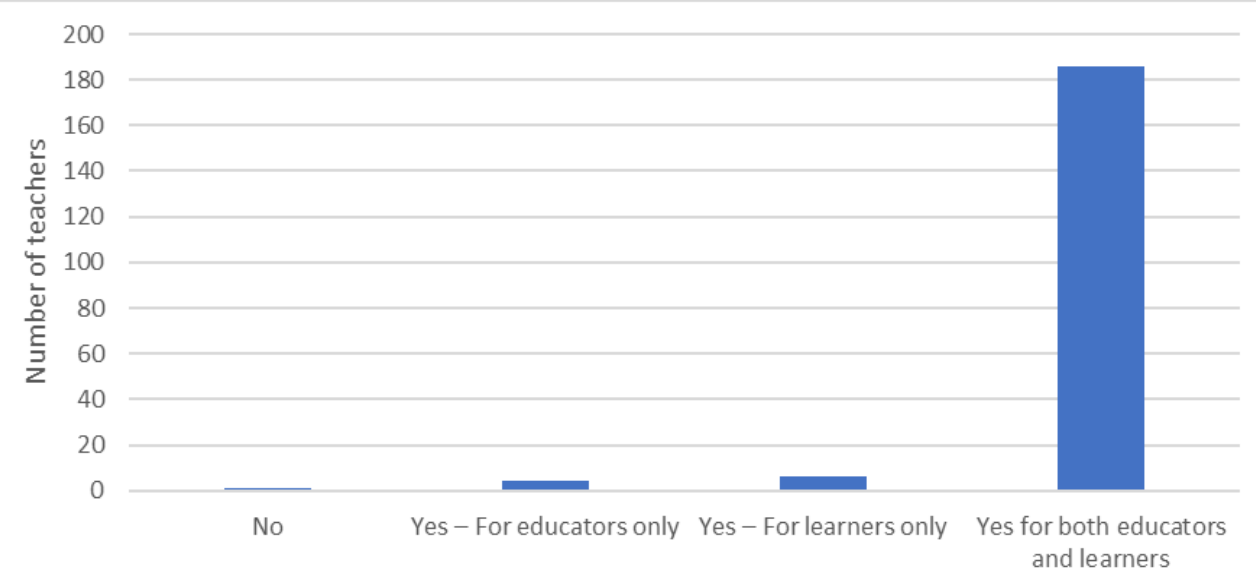

Teachers' responses 
Teachers' ICT ownership and use at home

In respect of personal ownership and use of technology at home, as displayed in Table 2, 133 (67\%) of the 197 surveyed teachers said they owned one or more of a smartphone, feature phone (non-smart cellphone) and/or tablet; 121 (61.5\%) confirmed that they owned a computer or laptop; 67 (34\%) printers in their homes, and $55(28 \%)$ had access to the internet from home.

Table 2: Teachers' ICT ownership and use at home

\begin{tabular}{|c|c|c|}
\hline ICT tool & $\begin{array}{c}\text { No. of teachers who } \\
\text { owned and used the tool } \\
\text { at home }\end{array}$ & Percentage \\
\hline $\begin{array}{c}\text { Smartphone, feature phone, } \\
\text { and/or tablet }\end{array}$ & 133 & $68 \%$ \\
\hline Computer (PC or laptop) & 121 & $61 \%$ \\
\hline Printer & 67 & $34 \%$ \\
\hline Internet & 55 & $28 \%$ \\
\hline
\end{tabular}

\section{School bans on use of personal digital devices}

Of the 197 teachers surveyed, 163 (83\%) indicated that their schools had banned learner use of personal digital devices, with the exception of calculators, on school premises. Meanwhile, 17 (9\%) of the teachers stated that their schools allowed learners to use personal digital devices on school premises. The remaining 17 (9\%) teachers did not respond to the question.

\section{Teacher technology readiness}

The findings in this sub-section are organised according to the four aforementioned technology readiness index (TRI) dimensions:

- optimism;

- innovativeness;

- discomfort; and

- insecurity.

Teachers' optimism about the use of ICTs

Figure 2 illustrates the findings from the survey questions probing teachers' degree of optimism about using ICTs. 
Figure 2: Teachers' optimism about the use of ICTs

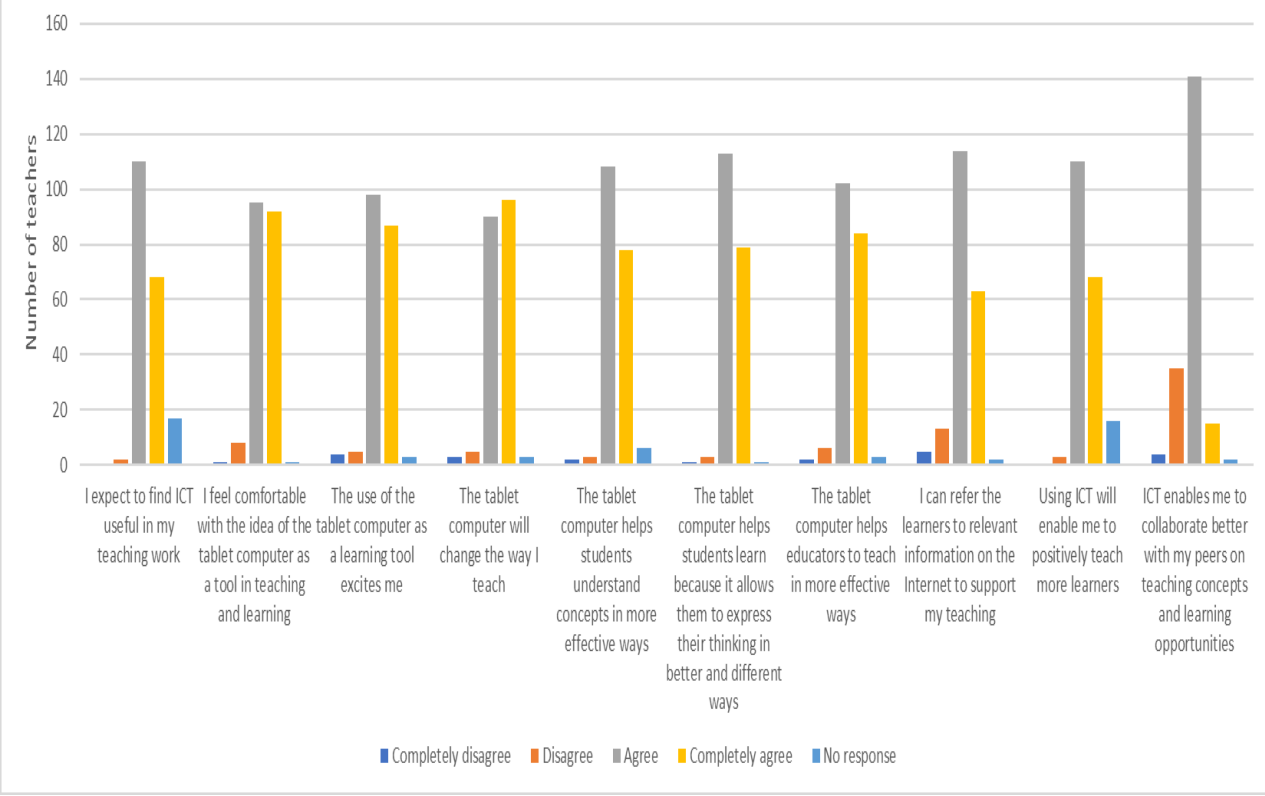

Ninety per cent of the surveyed teachers agreed (via an "agree" or "completely agree" response) with the statement that they expected to find ICTs useful in teaching their subjects, as presented in Figure 3. Ninety-five per cent of the teachers agreed that they were comfortable with the idea of a tablet as a tool for teaching and learning, and 94\% agreed that the use of tablets was exciting. With reference to their perception of using tablets for teaching, $94 \%$ agreed that tablets would change the way they teach. The same percentage agreed that tablets would assist learners in understanding concepts effectively. Furthermore, $97 \%$ of teachers agreed that the use of tablets would allow learners the freedom to express their views, $90 \%$ agreed or strongly agreed that ICTs would encourage positive learning experiences for learners, and $90 \%$ agreed or strongly agreed that they could refer learners to relevant content on the internet to support content covered in the classroom.

In reflecting on their own abilities, $94 \%$ of the teachers agreed that tablets could assist them in approaching teaching effectively, and $79 \%$ agreed that their colleagues could assist them in collaborating on teaching and learning opportunities.

Teachers' innovativeness in the use of ICTs

Figure 3 illustrates the findings from the survey questions probing teachers' degree of innovativeness in using ICTs. 
Figure 3: Teachers' innovativeness in the use of ICTs

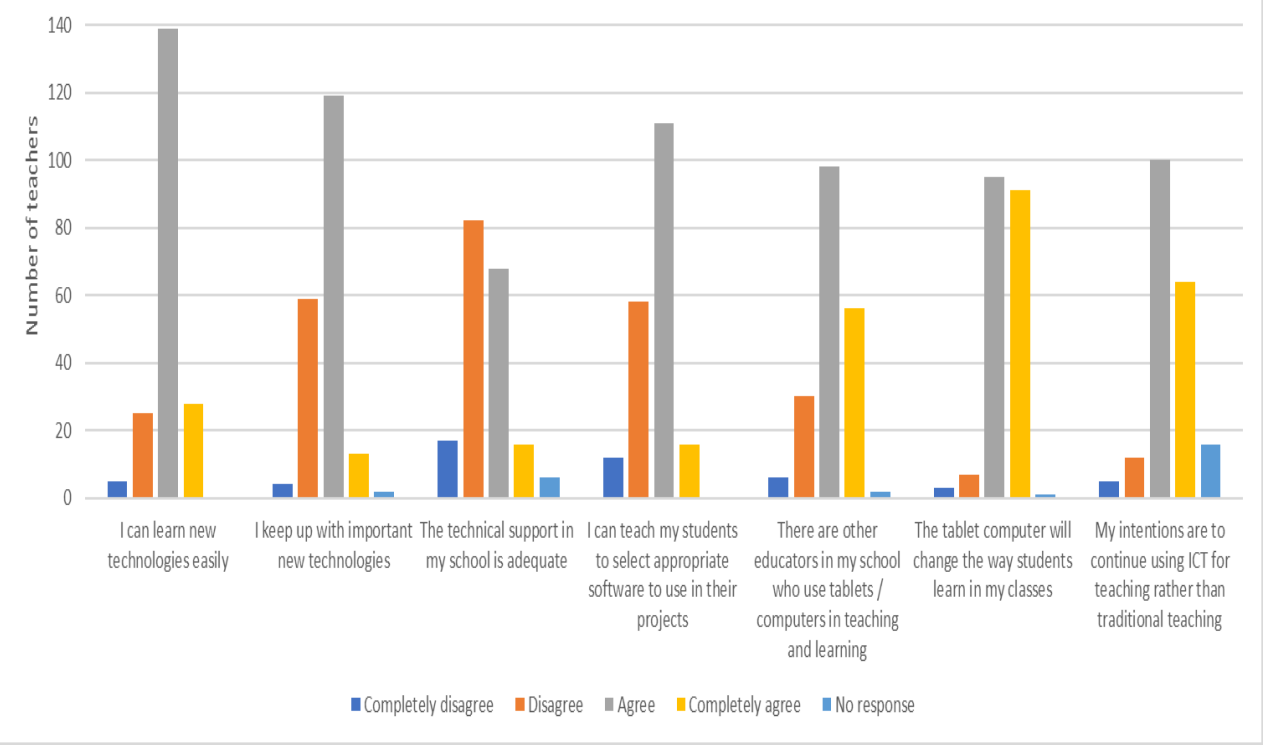

Eighty-five per cent of the teachers agreed (via an "agree" or "strongly agree" response) with the statement that they had the ability to easily learn new technologies, and $67 \%$ agreed that they were keeping up with new technologies. Forty-three per cent of the teachers agreed that technical support at their school was adequate, $64 \%$ agreed that they could teach learners to select appropriate software to use for their projects, and $78 \%$ agreed that teaching colleagues at their school used tablets or computers in the classroom for teaching. When teachers were probed about the impact of tablet computers in the classroom, $94 \%$ of the teachers agreed that it "will change the way students learn in my classes", and 83\% of the teachers agreed that they intended "to continue using ICT for teaching rather than traditional teaching".

\section{Teachers' discomfort with the use of ICTs}

Figure 4 represents the findings from the survey questions probing teachers' levels of discomfort with using ICTs. Because discomfort is an inhibitor, the description of findings is focused on disagreement with the potential discomforts posed to them, i.e., the percentages we report are the number of teachers who responded with "disagree" or "completely disagree" to each statement they were asked to respond to. 
Figure 4: Teachers' discomfort with the use of ICTs

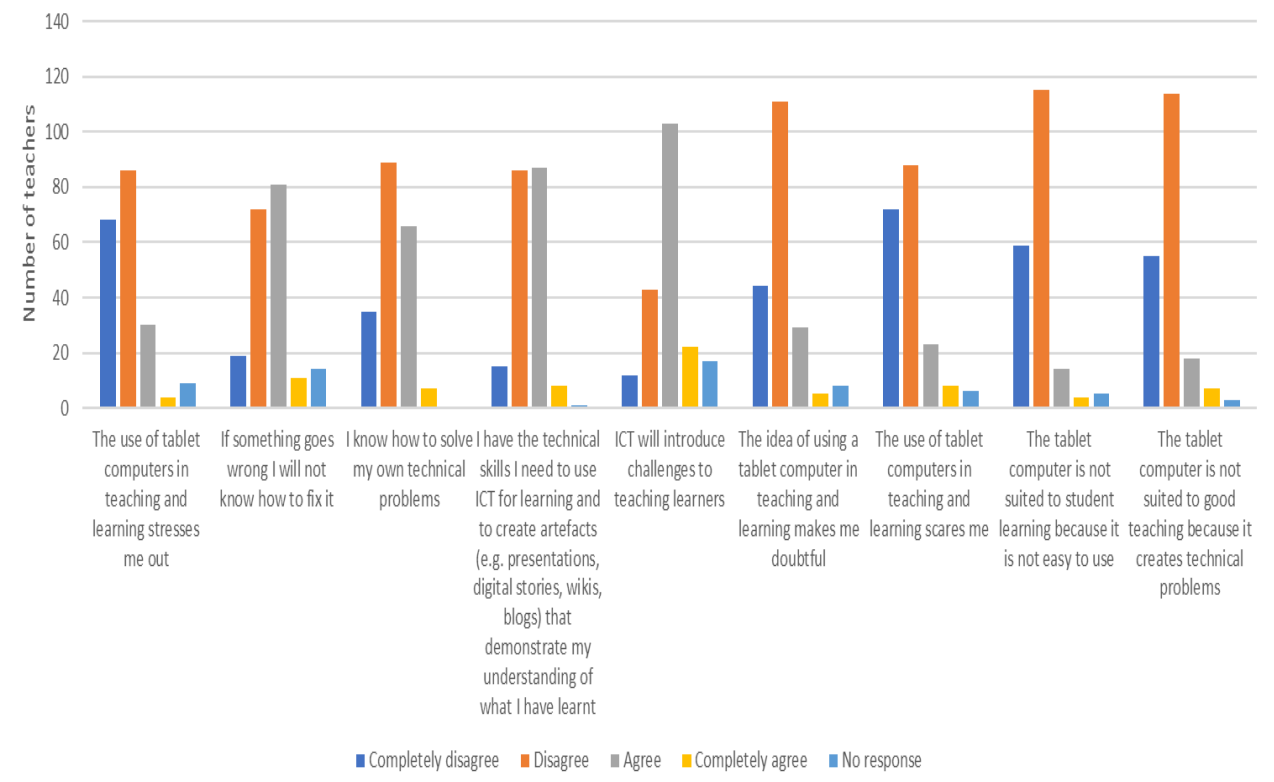

In some areas, the teacher responses suggested very little discomfort. Eighty-eight per cent of the teachers disagreed (via a "disagree" or "completely disagree" response) with the statement that "[t] he tablet computer is not suited to student learning because it is not easy to use", $86 \%$ disagreed with the statement that "[ $t]$ he tablet computer is not suited to good teaching because it creates technical problems", $81 \%$ disagreed with the statement that "use of tablet computers in teaching and learning scares me", 79\% disagreed with the statement that "[ $t]$ he idea of using a tablet computer in teaching and learning makes me doubtful", and $78 \%$ of the teachers disagreed with the statement that using tablets for teaching and learning "stresses me out". All these responses suggest high levels of comfort with ICT.

There were, however, indications of some substantial feelings of discomfort in other areas. Only $28 \%$ of teacher disagreed that "ICTs will introduce challenges to teaching learners", and fewer than half (46\%) of the teachers disagreed with the statement that "[i]f something goes wrong, I will not know how to fix it".

There were clear indications of discomfort in terms of some of the teachers' personal technical skills. A large number (63\%) of the teachers disagreed with the statement that "I know how to solve my own technical problems", and more than half (51\%) disagreed with the statement that "I have the necessary technical skills to use ICTs for learning and create artefacts (e.g., presentations, digital stories, wikis, blogs) that demonstrate my understanding of what I have learnt". 
Teachers' feelings of insecurity regarding the use of ICTs

Figure 5 represents the findings from the survey questions probing teachers' feelings of insecurity regarding the use of ICTs. Insecurity is an inhibitor and thus the results are, as with "discomfort" above, discussed in terms of a combination of "disagree" and "completely disagree" responses.

Figure 5: Teachers' feelings of insecurity regarding the use of ICTs

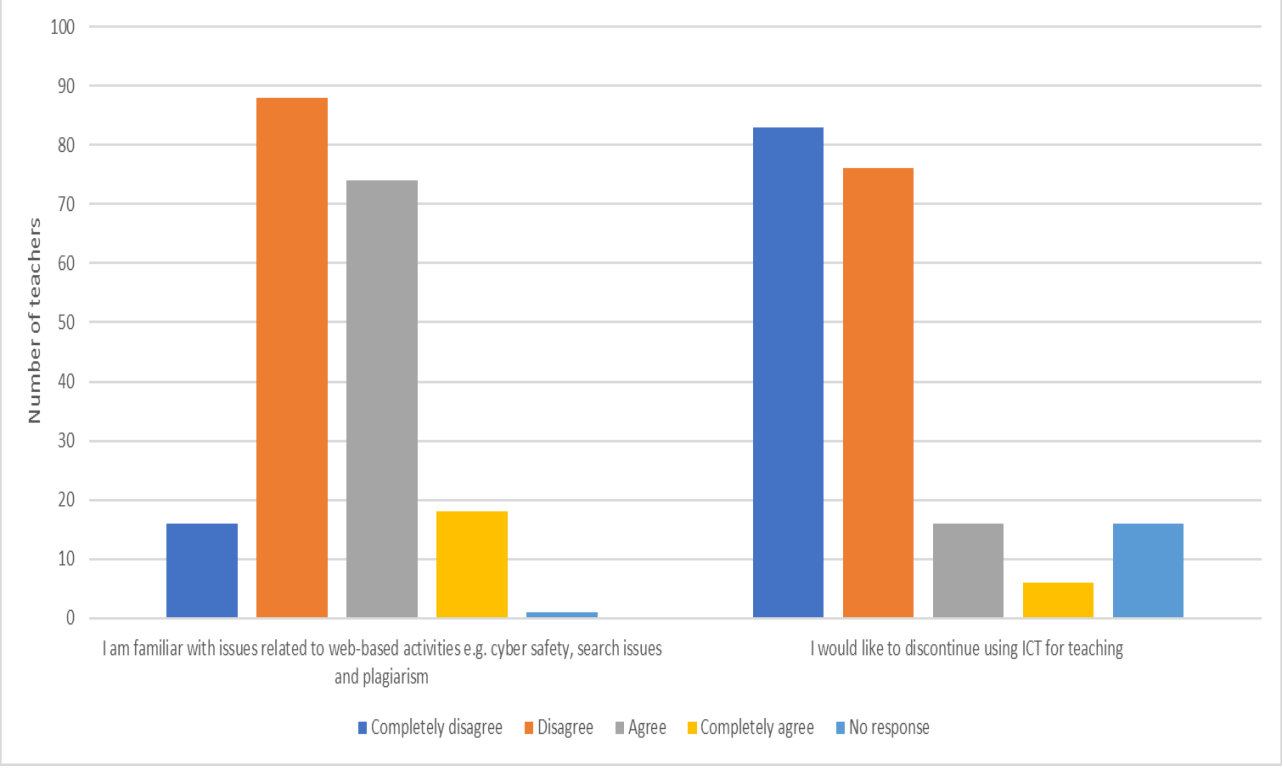

Fifty-three per cent of the teachers disagreed (via a "disagree" or "completely disagree" response) that they were "familiar with issues related to web-based activities, e.g., cyber safety, search issues and plagiarism". However, at the same time, only $11 \%$ of the teachers disagreed with the statement that "I would like to discontinue using ICT for teaching".

\section{Analysis and conclusions}

\section{Teachers'technology readiness}

\section{Optimism}

Most of the teachers were clearly optimistic about the use of ICT as tools for teaching and learning. There was a clear belief that tablets would change the approach to classroom interactions and awaken inactive learners. Teachers had a sense of control of the ICTs, which led them to believe that they could assist learners. Furthermore, the teachers had the perception that ICTs offered an efficient approach to teaching and learning, and they were optimistic about receiving the necessary technical support from their colleagues and the wider community. These findings resonate with those of Haßler, Major and Hennessy (2016) and Mouza and Barrett-Greenly (2015), who 
argue that teachers' optimism is produced by both the benefits associated with using ICTs for teaching and the digital skills they gain in the process.

\section{Innovativeness}

It was found that the majority of the teachers had confidence in their ability to be innovative in their adoption of ICTs. They believed in the technical support offered, believed they could guide learners in using software for projects, and had colleagues who were innovative and with whom they could collaborate in the quest to transform classroom interactions for learners. Kopcha (2012) provides similar findings, explaining how technical and administrative support coupled with colleagues' assistance influences teachers' innovative approaches to using ICTs for teaching and learning. Rogers $(1983,2003)$ refers to teachers who are the first to use technologies in society as innovators, and they not only form the support structure for early adopters but are also quick to test any technology.

\section{Discomfort}

The results were mixed on the matter of discomfort. There were low levels of teacher discomfort regarding the suitability of tablets for teaching and learning, and ease of use for students, and low levels of general fear, doubt and stress among the teachers about using ICTs for teaching and learning. But, at the same time, there were high levels of discomfort expressed regarding the "challenges to teaching learners", fixing technical problems, and having the necessary personal ICT skills.

\section{Insecurity}

Slightly more than $50 \%$ of the teachers surveyed indicated concern over their lack of familiarity with matters of cyber safety, search issues, and plagiarism, but only for a very small number of teachers did this concern translate into a desire to stop using ICTs for teaching.

Overall, it would appear that the teachers' strong feelings of optimism and innovativeness in respect of ICT adoption were the technology readiness factors allowing them to overcome most of their feelings of discomfort and insecurity.

\section{Implications for South Africa Connect}

The generally positive teacher technology readiness findings discussed above would seem to augur well for the objectives of the South Africa Connect national broadband policy. But there are clearly some teacher training and empowerment requirements that must be addressed if the teaching and learning objectives of South Africa Connect policy are to be met in South African rural schools. More than half (and in several cases substantially more than three-quarters) of the teachers surveyed indicated that they felt discomfort in respect of:

- the challenges inherent in the teaching of learners via ICTs;

- their ability to fix the technical problems that will inevitably arise; and 
- having the necessary personal ICT skills "to use ICTs for learning and create artefacts (e.g., presentations, digital stories, wikis, blogs)”.

All three elements need to be addressed via teacher training if South African rural schools are to succeed in ways envisioned by South Africa Connect. The identification of these three elements is a practical contribution that this research offers to understanding how to optimise the adoption of ICTs in South African rural schools.

Also, the prohibitions we found at many schools against student use of personal digital devices (with the exception of calculators) on school premises suggest a potential disconnect between bottom-up sentiment at the level of rural schools and the top-down South Africa Connect drive for increased ICT use. Section 36(4)(b) of the South Africa Schools Act of 1996 gives each School Governing Body (SGB) a mandate to determine restrictions on activities that may be harmful to learners on school premises (RSA, 1996). Thus, the interpretation of what is harmful to learners rests with SGBs-and the SGBs have created the aforementioned policies about student use of personal digital devices. Also of note is our finding, cited above, that the majority (83\%) of the teachers surveyed said that their schools prohibited use of personal digital devices on school premises, thereby potentially limiting the learners' ability to acquire digital education. This is while the teachers themselves acknowledge the usefulness of ICTs in teaching. The core concern on the part of the SGBs and the teachers seems to be how to avoid student use of personal digital devices, on school premises, for non-educational purposes.

South Africa Connect's stated critical success factors include "implementation of measures that will enable uptake and usage. Examples include the availability of electronic educational content, the use of tablets and mobile devices in schools [...]" (DoC, 2013, p. 40). Schools' bans on learner use of personal digital devices on school premises potentially run counter to this South Africa Connect objective.

We recommend that personal digital device use for instructional and learning purposes be permitted in South African classrooms, in line with the objectives of South Africa Connect. At the same time, we realise that schools do experience practical issues in controlling non-educational use of personal devices by learners inside and outside the classroom. Accordingly, we are of the view that the schools in question should rescind or amend their policies prohibiting student use of personal digital devices at school—or, failing that, that the government should revise the relevant section of the Schools Act in such a way as to take the power to dictate classroom ICT use away from SGBs, thus expediting the operationalisation of South Africa Connect and the broader National Development Plan, while at the same time ensuring that the use of personal digital devices at schools is limited to usage for educational purposes. 


\section{References}

Adukaite, A., Van Zyl, I., Er, Ş., \& Cantoni, L. (2017). Teacher perceptions on the use of digital gamified learning in tourism education: The case of South African secondary schools. Computers and Education, 111(August), 172-190. https://doi.org/10.1016/j.compedu.2017.04.008

Alsabawy, A., Cater-Steel, A., \& Soar, J. (2011). Measuring e-learning system success (Research in progress). In PACIS 2011 Proceedings (Paper 15). Brisbane.

Ampofo, S. Y., Bizimana, B., Mbuthi, J., Ndayambaje, I., Ogeta, N., \& Orodho, J. A. (2014). Information communication technology penetration and its impact on education: Lessons of experience from selected African countries of Ghana, Kenya and Rwanda. Journal of Information Engineering and Applications, 4(11), 84-95.

Avgerou, C. (2008). Information systems in developing countries: A critical research review. Journal of Information Technology, 23(3), 133-146. https://doi.org/10.1057/palgrave.jit.2000136

Barakabitze, A. A., Lazaro, A.W., Ainea, N., Mkwizu, M. H., Maziku, H., Matofali, A. X., Iddi, A., \& Sanga, C. (2019). Transforming African education systems in Science, Technology, Engineering, and Mathematics (STEM) using ICTs: Challenges and opportunities. Education Research International, 2019, 1-29. https://doi.org/10.1155/2019/6946809

Botha, A., Herselman, M., Rametse, S., \& Maremi, K. (2017). Barriers in rural technology integration: A case study from the trenches. In P. Cunningham, \& M. Cunningham (Eds.), IST-Africa 2017 Conference Proceedings (pp. 1-10). https://doi.org/10.23919/ISTAFRICA.2017.8102349

Chen, X. (2013). Tablets for informal language learning: Student usage and attitudes. Language Learning E Technology, 17(1), 20-36.

Department of Basic Education. (2017). Rural Education Draft Policy. Retrieved from http:// pmg-assets.s3-website-eu-west-1.amazonaws.com/180126draftruraledupolicy.pdf

Department of Communications (DoC). (2013). South Africa Connect: Creating Opportunities, Ensuring Inclusion: South Africa's Broadband Policy. Retrieved from https://www.gov.za/documents/electronic-communications-act-south-africaconnect-creating-opportunity-ensuring-inclusion

Department of Telecommunications and Postal Services (DTPS). (2016). National Integrated ICT Policy White Paper. Retrieved from https:/www.gov.za/documents/electroniccommunications-act-national-integrated-ict-policy-white-paper-3-oct-2016-0000

DTPS. (2019). Policy on High Demand Spectrum and Policy Direction on the Licensing of a Wireless Open Access Network.

Eberhard, B., Podio, M., Alonso, A. P., Radovica, E., Avotina, L., Peiseniece, L., Sendon, M.C., Lozano, A.G., \& Solé-Pla, J. (2017). Smart work: The transformation of the labour market due to the fourth industrial revolution (I4.0). International Journal of Business and Economic Sciences Applied Research, 10(3), 47-66.

Falloon, G. (2013). Young students using iPads: App design and content influences on their learning pathways. Computers E Education, 68(October), 505-521. https://doi.org/10.1016/j.compedu.2013.06.006

Fardon, R., \& Furniss, G. (Eds.) (1994). African languages, development and the state. London: Routledge. 
Frohberg, D., Göth, C., \& Schwabe, G. (2009). Mobile learning projects: A critical analysis of the state of the art. Journal of Computer Assisted Learning, 25(4), 307-331.

https://doi.org/10.1111/j.1365-2729.2009.00315.x

Flyvbjerg, B. (2006). Five misunderstandings about case-study research. Qualitative Inquiry, 12(2), 219-245. https://doi.org/10.1177/1077800405284363

Gibson, D., Broadley, T., Downie, J., \& Wallet, P. (2018). Evolving learning paradigms: Re-setting baselines and collection methods of information and communication technology in education statistics. Journal of Educational Technology E Society, 21(2), 62-73.

Haßler, B., Major, L., \& Hennessy, S. (2016). Tablet use in schools: A critical review of the evidence for learning outcomes. Journal of Computer Assisted Learning, 32(2), 139156. https://doi.org/10.1111/jcal.12123

Hankel, L., Burgess, M., Roux, K., Van Deventer, A., Ford, M., Smith, R., \& Govender, S. (2017). Study on the accuracy of school location information in South Africa. South African Journal of Geomatics, 6(2), 142-154. https://doi.org/10.4314/sajg.v6i2.1

Hargittai, E. (2010). Digital na(t)ives? Variation in internet skills and uses among members of the 'net generation'. Sociological Inquiry, 80(1), 92-113.

https://doi.org/10.1111/j.1475-682X.2009.00317.x

Hennessy, S., Harrison, D. J., \& Wamakote, L. (2010). Teacher factors influencing classroom use of ICT in Sub-Saharan Africa. Itupale Online Journal of African Studies, 2(2010), 39-54.

Herselman,M., \& Botha, A.(2014).Designing and implementing an information communication technology for rural education development (ICTARED) initiative in a resource constrained environment: Nciba school district, Eastern Cape, South Africa. Pretoria: CSIR Meraka.

Ifenthaler, D., \& Schweinbenz, V. (2013). The acceptance of tablet-PCs in classroom instruction: The teachers' perspectives. Computers in Human Behavior, 29(3), 525534. https://doi.org/10.1016/j.chb.2012.11.004

Kafyulilo, A. (2014). Access, use and perceptions of teachers and students towards mobile phones as a tool for teaching and learning in Tanzania. Education and Information Technologies, 19(1), 115-127. https://doi.org/10.1007/s10639-012-9207-y

Kaliisa, R., \& Picard, M. (2017). A systematic review on mobile learning in higher education: The African perspective. Turkish Online Journal of Educational Technology, 16(1), $1-18$.

Kalinga, A. E., Bagile, R. B. B., \& Trojer, L. (2006). An interactive e-learning management system (e-LMS): A solution to Tanzanian secondary schools' education. International Journal of Human and Social Sciences, 1(4), 250-253.

Kopcha, T. J. (2012). Teachers' perceptions of the barriers to technology integration and practices with technology under situated professional development. Computers $\mathcal{E}^{\circ}$ Education, 59(4), 1109-1121. https://doi.org/10.1016/j.compedu.2012.05.014

Lai, M. (2008). Technology readiness, internet self-efficacy and computing experience of professional accounting students. Campus-Wide Information Systems, 25(1), 18-29. https://doi.org/10.1108/10650740810849061

Lee, A. S. (1989). A scientific methodology for MIS case studies. MIS Quarterly, 13(1), 3350. https://doi.org/10.2307/248698 
Liebenberg, J., Benade, T., \& Ellis, S. (2018). Acceptance of ICT: Applicability of the unified theory of acceptance and use of technology (UTAUT) to South African students. The African Journal of Information Systems, 10(3), 160-173.

Marais, M., \& Van Biljon, J. (2017). Social mapping for supporting sensemaking and collaboration: The case of development informatics research in South Africa. In P. Cunningham, \& M. Cunningham (Eds.), IST-Africa 2017 Conference Proceedings (pp. 1-10). https://doi.org/10.23919/ISTAFRICA.2017.8102336

Mestry, R., \& Ndhlovu, R. (2014). The implications of the National Norms and Standards for School Funding policy on equity in South African public schools. South African Journal of Education, 34(3), 1-11. https://doi.org/10.15700/201409161042

Mouza, C., \& Barrett-Greenly, T. (2015). Bridging the app gap: An examination of a professional development initiative on mobile learning in urban schools. Computers and Education, 88, 1-14. https://doi.org/10.1016/j.compedu.2015.04.009

Mwapwele, S., Marais, M., Dlamini, S., \& Van Biljon, J. V. (2019). ICT support environment in developing countries: The multiple cases of school teachers in rural South Africa. In P. Cunningham, \& M. Cunningham (Eds.), IST-Africa 2019 Conference Proceedings (pp. 1-12). https://doi.org/10.23919/ISTAFRICA.2019.8764859

Ngwenyama, O., Andoh-Baidoo, F. K., Bollou, F., \& Morawczynski, O. (2006). Is there a relationship between ICT, health, education and development? An empirical analysis of five West African countries from 1997-2003. The Electronic Journal of Information Systems in Developing Countries, 23(5), 1-11.

https://doi.org/10.1002/j.1681-4835.2006.tb00150.x

National Planning Commission (NPC). (2012). National Development Plan 2030: Our Future - Make It Work. Retrieved from https://www.gov.za/sites/default/files/gcis document/201409/ndp-2030-our-future-make-it-workr.pdf

Omoniyi, T., \& Quadri, A. T. (2013). Perceived competence of Nigerian secondary schools teachers in the use of information and communication technology (ICT). Journal of Education and Practice, 4(10), 157-164.

Osakwe, J., Dlodlo, N., \& Jere, N. (2017). Where learners' and teachers' perceptions on mobile learning meet: A case of Namibian secondary schools in the Khomas region. Technology in Society, 49(May),16-30.https://doi.org/10.1016/j.techsoc.2016.12.004

Parasuraman, A., \& Colby, C. L. (2015). An updated and streamlined technology readiness index: TRI 2.0. Journal of Service Research, 18(1), 59-74.

https://doi.org/10.1177/1094670514539730

Partin, C. M., \& Lauderdale, S. (2013). Bringing it all together: Interdisciplinary perspectives on incorporating mobile technologies in higher education. In L. Wankel \& P. Blessinger (Eds.), Increasing student engagement and retention using mobile applications: Smartphones, Skype and texting technologies (pp. 83-114). Bingley, UK: Emerald. https://doi.org/10.1108/S2044-9968(2013)000006D006

Porter, G., Hampshire, K., Milner, J., Munthali, A., Robson, E., De Lannoy, A., ... Abane, A. (2016). Mobile phones and education in Sub-Saharan Africa: From youth practice to public policy. Journal of International Development, 28(1), 22-39. https://doi.org/10.1002/jid.3116

Rambe, P., \& Ng'ambi, D. (2014). Learning with and from Facebook: Uncovering power asymmetries in educational interactions. Australasian Journal of Educational Technology, 30(3), 312-325. https://doi.org/10.14742/ajet.116 
Rena, R. (2006). Higher education in Africa - A case of Eritrea. Journal of Educational Planning and Administration, 21(2), 125-140.

Rena, R. (2008). The Internet in tertiary education in Africa: Recent trends. International Journal of Computing and ICT Research, 2(1), 9-16.

Republic of South Africa (RSA). (1996). South African Schools Act, No. 84 of 1996.

Roberts, N., \&Vänskä,R. (2011). Challenging assumptions: Mobile Learning for Mathematics Project in South Africa. Distance Education, 32(2), 243-259. https://doi.org/10.1080/01587919.2011.584850

Rogers, E. M. (1983). Diffusion of innovation (3rd ed.). London: Collier Macmillan.

Rogers, E. M. (2003). Diffusion of innovations (5th ed.). New York: Free Press.

Summak, M. S., Baglibel, M., \& Samancioglu, M. (2010). Technology readiness of primary school teachers: A case study in Turkey. Procedia - Social and Behavioral Sciences, 2(2), 2671-2675.https://doi.org/10.1016/j.sbspro.2010.03.393

Waller, P. P., \& Maxwell, K. L.H. (2017). Mathematics teachers' perceptions of resources and curriculum availability in post-apartheid schooling. International Journal of Science and Mathematics Education, 15(4), 741-757. https://doi.org/10.1007/s10763-016-9713-2

Yidana,I., \& Maazurre, C. (2012). Integrating ICT into teacher education curriculum: Faculty perceptions of their technology professional development needs in two Ghanaian universities. Journal of Continuing, Open and Distance Education, 2(1), 175-199. 